\title{
ЗБІЛЬШЕННЯ ЗЧЕПЛЕННЯ БЕТОНУ ЗІ СКЛОКОМПОЗИТНОЮ АРМАТУРОЮ ЗА РАХУНОК ПОКРИТТЯ СПЕЦАЛЬНИМИ РЕЧОВИНАМИ, ЯК ВАРІАНТ ОПТИМІЗАЦІЇ ВИРОБНИЧОЇ БАЗИ БУДІВНИЦТВА
}

\section{INCREASE OF ADHESION OF CONCRETE WITH FIBERGLASS REINFORCEMENTS BY USING THE COATING WITH SPECIAL SUBSTANCES, AS OPTIMIZATION OF CONSTRUCTION INDUSTRY}

Чапюк О.С., к.т.н., доц., Гришкова А.В., асп., Кислюк Д.Я., к.т.н., доц., Пахолюк О.А., к.т.н., доц., (Луцький національний технічний університет, м. Луцьк), Філіпчук С.В., к.т.н., доц., (Національний університет водного господарства та природокористування, м. Рівне)

Chapiuk O., Ph.D. in Engineering, Associate Professor, Grishkova A., postgraduate student, Kysliuk D., Ph.D. in Engineering, Associate Professor, Pakholiuk O., Ph.D. in Engineering, Associate Professor (Lutsk National Technical University, Lutsk), Filipchuk S., Ph.D. in Engineering, Associate Professor (National university of water management and nature resources use, Rivne)

Досліджено вплив покриття склокомпозитних стержнів водовідштовхувальною композицією «СІЛОЛ®» українського виробництва на зчеплення арматури з бетоном для оптимізації виробничої бази будівництва. При покритті ним склокомпозитної арматури та збільшенні довжини анкерування, збільшується $i$ граничне напруження в стержнях. Напруження металевих стержнів дещо більще, ніж у зразках з композитною арматурою, але при дворазовому покритті ситуація змінюється на користь склопластику.

The construction industry consists of many components, but the most important of them is the production and use of reinforced concrete. Recently, the use of composite concrete is increasingly observed in facilities where the use of non-metallic reinforcement is more appropriate: road, hydraulic, tunnel construction and residential and public, where there is no fire hazard. One of the disadvantages of fiberglass reinforcement is low water absorption, which can adversely affect the strength and durability of structures. There are a wide range of water-repellent materials at Ukrainian markets, but the most famous Ukrainian invention is the composition "SILOL ${ }^{\circledR}$ ". It is a liquid composition, which is most often applied to the surface of road structures and for impregnation of concrete, reinforced concrete, brick to give them water-repellent properties. After processing, the materials become much more resistant to water and various solutions, frost resistance and durability. The solution penetrates to a considerable depth of $2-8 \mathrm{~mm}$ and turns into an elastic resin, which gives waterrepellent properties of materials. As a result of covering of composite rods with this material, they got weather resistance, durability and high resistance to water and salt 
solutions, frost. The research was to investigate the influence of the covering of composite fiberglass reinforcing bars with the material "SILOL ${ }^{\circledR}$ " on the adhesion with a concrete. When it covers the fiberglass reinforcement and increases the length of the anchoring, the maximum stress in the rods also increases. The stress of metal rods is slightly higher than in samples with composite reinforcement, but with double coating changes the situation for fiberglass advantage. In samples with a longer anchoring length (10d and 15d), the strength of samples with double-coated composite reinforcement is higher by $1.7 \%$ and $7.3 \%$ compared to samples with metal rods.

Ключова слова: склокомпозитна арматура, АКС800, А500С, клас бетону С12/15, водовідитовхувальна композичія «СІЛОЛ®», зчеплення, бетонна призма, поперечний переріз, виробнича база будівництва.

Keywords: fiberglass reinforcement, AKC800, A500C, concrete C12/15, water resistant composition "SILOL ${ }^{\circledR}$ ", adhesion, anchoring length, construction industry.

Вступ. Виробнича база будівництва складається 3 багатьох складових, але найголовнішою 3 них $є$ виробництво та використання залізобетону. Останнім часом все частіше спостерігається використання композитобетону в об'єктах, де застосування неметалевої арматури $є$ доцільнішим: дорожне, гідротехнічне, тунельне будівництво та житлове i громадське, де немає пожежної небезпеки (фундаменти, басейни тощо).

Постановка проблеми та задачі дослідження. Одним 3 недоліків склопластикової арматури $є$ незначне водопоглинання, що може негативно впливати на міцність та довговічність конструкцій. На будівельному ринку представлено досить широкий вибір водовідштовхувальних матеріалів, але найвідомішим українським винаходом $\epsilon$ композиції «СІЛОЛ®». В результаті обробки композитних стержнів цим матеріалом вони набувають більшу атмосферостійкість, довговічність, стійкість до дії води і розчинів солей. У роботі було поставлено задачу дослідити вплив покриття склокомпозитних стержнів цим матеріалом на зчеплення їх з бетоном.

Матеріали дослідних зразків. Для дослідження виготовили бетонні призми розмірами $150 * 150 \mathrm{Mm}$ і по три висотою $5 \mathrm{~d}$, $10 \mathrm{~d}$ та $15 \mathrm{~d} 3$ центрально-розташованою склопластиковою арматурою (d - діаметр стержнів 12мм класу АКС 800), яка покрита одним чи двома шарами водовідштовхувального засобу.

Як правило, «СІЛОЛ®» - це рідка силоксанова композиція, яка найчастіше наноситься на поверхню дорожніх конструкцій та для просочення бетону, залізобетону, цегли для надання їм водовідштовхувальних властивостей. Після обробки матеріали набувають значно більшої стійкості до дії води та різних розчинів, морозостійкості та довговічності. Розчин проникає на досить значну глибину - 2-8 мм i перетворюється в еластичну смолу, яка надає водовідштовхувальних властивостей матеріалам [1]. 
Експериментальні зразки виготовлялися з бетону класу C12/15 3 такими механічними характеристиками: кубикова міцність у віці 28 діб $f_{c}=19,45$ МПа; призмова міцність $-f_{c d}=15,35$ МПа.

Конструкція дослідних зразків. Рідким матеріалом «СІЛОЛ®» покривалась поверхня склопластикової арматури суцільними рівномірними шарами. Другий шар наносився після повного висихання попереднього. Після його застосування утворилася прозора матова плівка.

Стержні арматури розташовувались в бетонних призмах так, щоб їхні поздовжні осі співпадали, а виступаючі частини стержнів дозволяли 3 одного боку закріплювати їх в захваті розривної машини, а 3 другого (вільного) - вимірювати переміщення відносно торця призм. Для уникнення пошкодження поверхні композитної арматури, на вільний кінець арматури приклеювали металеву трубку (рис. 1), яка скріплювалась зі стержнем епоксидною смолою $з$ додаванням кварцового піску у співвідношенні 1:1 [2].

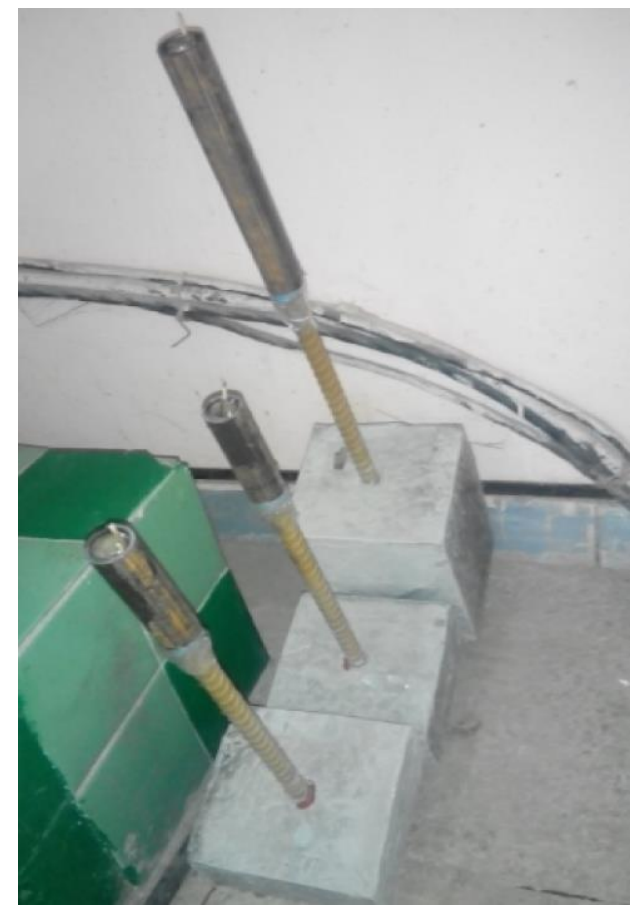

Рис. 1. Захист композитних арматурних стержнів від пошкодження в захваті розривної машини 
Методика випробування бетонних призм. Дослідження зчеплення композитної арматури з бетоном були виконані шляхом висмикування склокомпозитних стержнів 3 бетонних призм в розривній гідравлічній машині 3 використанням спеціального натяжного пристрою. Під час навантажень вимірювали переміщення вільного кінця стержня відносно торця призми індикатором годинникового типу з ціною поділки 0,001 мм (рис. 2) [3].

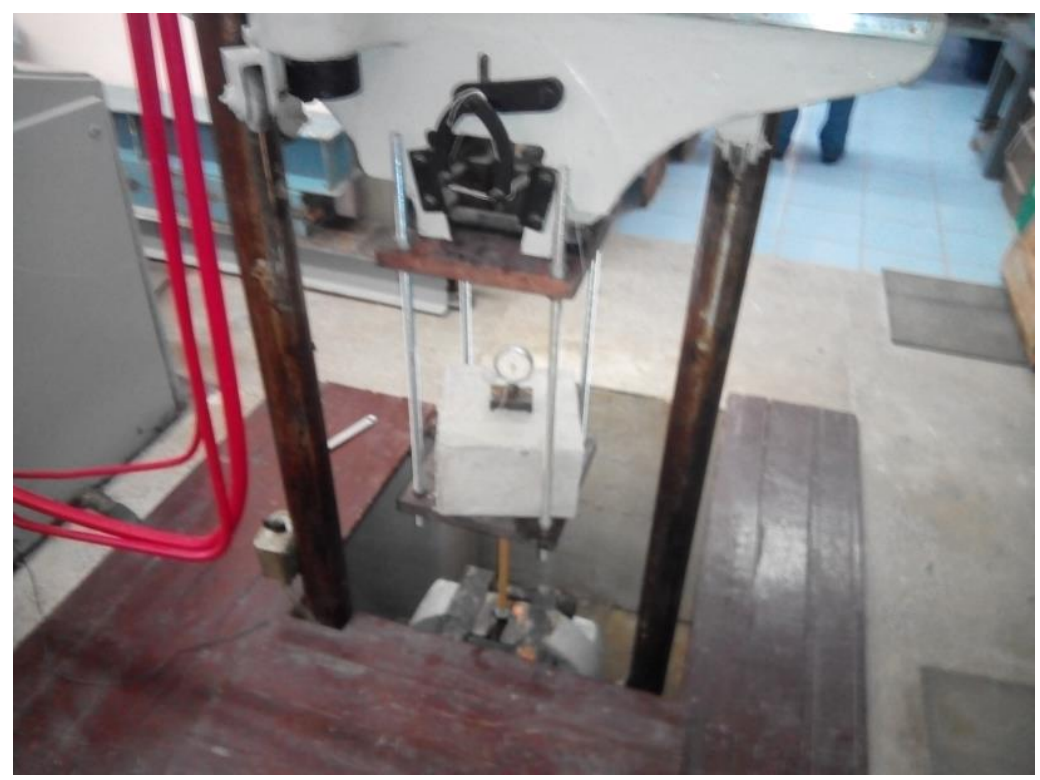

Рис. 2. Загальний вигляд випробування зразків у розривній машині

Результати досліджень. Зразки позначалися в залежності від кількості покриття арматурних стержнів матеріалом «СІЛОЛ®» та висоти бетонних призм (буква „П” - призма, перше число - довжина анкерування $(5 \mathrm{~d}, 10 \mathrm{~d}, 15 \mathrm{~d})$, друге - діаметр арматури $\mathrm{d}=12 \mathrm{mм})$, третє - кількість шарів покриття стержнів матеріалом «СІЛОЛ®» (0 - ні разу не покрита; 1 - один шар; 2 - два шари). Зразки вважалися зруйновані, якщо проковзування вільного кінця склокомпозитного стержня відносно бетонної призми складало 0,2мм.

$\mathrm{y}$ найменших зразках 3 довжиною анкерування склокомпозтної арматури 60мм П-5d/12-0, П-5d/12-1, П-5d/12-2 граничне значення $\delta_{u}=$ 0,2 мм було досягнуто при напруженнях в стержнях відповідно $f_{y d}=98,7$; 
105,$1 ; \quad 109,2$ МПа. У зразках П-10d/12-0, П-10d/12-1, П-10d/12-2 переміщення $\delta_{u}=0,2$ мм отримано при напруженнях в стержнях відповідно $f_{y d}=184,3 ; 217,5 ; 228,6$ МПа, а в зразках П-15d/12-0, П-15d/12-1, П-15d/12-2 при напруженнях в стержнях відповідно $f_{y d}=376,7 ; 403,3 ; 411,4$ МПа. Для наочності показано і напруження в металевих стержнях (рис. 3). В зразках зі звичайною металевою арматурою серповидного профілю діаметром 16 мм класу А500С 3 довжиною анкеруваня 5d, 10d, 15d у зразках Пм$5 \mathrm{~d} / 16, \quad$ Пм-10d/16,Пм-15d/16 (без покриття водовідштовхувальною композицією, клас бетону C12/15) руйнівне напруження в стержнях склало відповідно $f_{y d}=116,2,223,6,382,5$ МПа, що на 15,$5 ; 17,8$ та $1,6 \%$ більше ніж у зразках П-5d/12-0, П-10d/12-0 та П-15d/12-0.

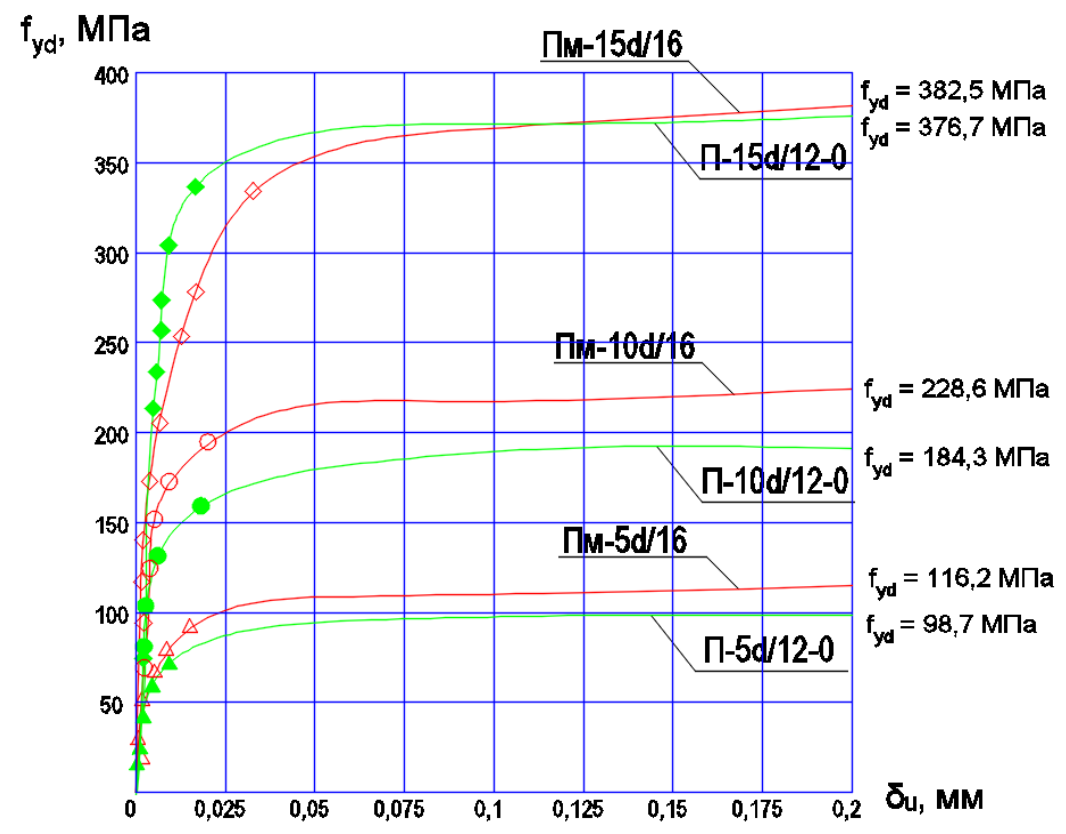

Рис. 3. Зміна проковзування $\delta$ стержнів залежно від напруження $f_{y d}$ :

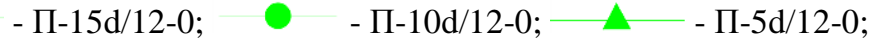
- Пм-15d/16; - Пм-10d/16; - Пм-5d/16

Значення дотичних напружень зчеплення стержнів з бетоном $\tau_{u}$ у зразках довжиною анкерування $l_{a n}=60$ мм склали: для зразків П-5d/12-0, П-5d/12-1 та П-5d/12-2 відповідно $\tau_{u}=4,9 ; 5,2$ та 5,5 МПа. Різниця між дотичними напруженнями в зразках, непокритих композицією 
«СІЛОЛ®» та покритих одноразово, складає 5,8 \%, а в порівнянні 3 дворазовим - 10,9\%. При довжині анкерування $l_{a n}=120$ мм дотичні напруження в зразках П-10d/12-0, П-10d/12-1 та П-10d/12-2 склали відповідно $\tau_{u}=4,6 ; 5,4$ та 5,7 МПа. При одноразовому покритті значення на $14,8 \%$ більші за непокриті, а при дворазовому ще на $4,5 \%$. В зразках П-15d/12-0, П-15d/12-1 та П-15d/12-2 з $l_{a n}=180$ мм склали відповідно $\tau_{u}=$ 6,$3 ; 6,7$ та 6,9 МПа. Дотичні напруження одноразово покритих зразків на $6,0 \%$ більші від непокритих, а дворазово покритих на 8,7 \%. В зразках Пм$5 \mathrm{~d} / 16$, Пм-10d/16 та Пм-15d/16 з металевою арматурою діаметром 16 мм, що вважається рівноміцною склокомпозитним стержням діаметром 12 мм АКС 800, значення дотичних напружень склали відповідно $\tau_{u}=5,8 ; 5,6$ та 6,4 МПа.

Дотичні напруження зчеплення арматури з бетоном в зразках $3 l_{a n}=5 \mathrm{~d}$ і металевою арматурою Пм-5d/16 на 15,5 \% більші композитних П-5d/12-0, а в порівнянні з дворазово покритими стержнями АКС 800 лише на 1,7 \%. При $l_{a n}=10 \mathrm{~d}$ різниця дотичних напружень між Пм-10d/16 та П-10d/12-0 становить $17,8 \%$, а порівняно $з$ П-10d/12-2 вже на 1,7 \% менше. Значення $\tau_{u}$ в зразках з $l_{a n}=15 \mathrm{~d}$ і стальною арматурою Пм- $15 \mathrm{~d} / 16$ на $1,6 \%$ більші ніж 3 склокомпозитною П-15d/12-0, а відносно зразків 3 дворазовим покриттям стержнів АКС 800 вже на 7,3\% менші.

Отже, ми бачимо, що при покритті склокомпозитної арматури матеріалом «СІЛОЛ®» та збільшенні довжини анкерування, збільшується і граничне напруження в стержнях. В усіх зразках руйнівне напруження металевих стержнів дещо більше ніж у зразках з композитною арматурою, але при дворазовому покритті ситуація змінюється на користь склопластику.

Однозначно можна сказати, що з усіх факторів, найбільше значення мають призми 3 композитною склопластиковою арматурою, які покриті в два шари розчином «СІЛОЛ®», звідси випливає що за допомогою цього матеріалу можна збільшити зчеплення арматури 3 важким бетоном, довговічність арматури, а також і конструкції.

\section{Висновки}

1. Експериментально підтверджено, що покриття склокомпозитних стержнів водовідштовхувальною композицією «СІЛОЛ®» українського виробництва суттєво покращує зчеплення арматури з бетоном, що сприяє оптимізації виробничої бази будівництва.

2. При довжині анкерування $5 \mathrm{~d}$ в зразках, непокритих водовідштовхувальною композицією порівняно з призмами з одноразово покритою композитною арматурою, напруження складають 5,8 \%, а в порівнянні з дворазовим - 10,9\%. 
3. При більшій висоті бетонних призм $\left(l_{a n}=10 \mathrm{~d}\right)$ в зразках 3 одноразовим покриттям значення на 14,8 \% більші за непокриті, а при дворазовому ще на $4,5 \%$.

4. При найбільшій висоті бетонних призм $\left(l_{a n}=15 \mathrm{~d}\right)$ напруження одноразово покритих зразків на 6,0 \% більші від непокритих, а дворазово покритих на 8,7\%.

5. Міцність зразків 3 найменшою довжиною анкерування $5 \mathrm{~d}$ i металевою арматурою Ø16А500C на $15,5 \%$ більша від зразків 3 непокритою склокомпозитною арматурою Ø12АКС 800 , а в порівнянні 3 дворазово покритими стержнями лише на $1,7 \%$.

6. В зразках з більшою довжиною анкерування (10d та $15 \mathrm{~d})$ міцність зразків з дворазово покритою композитною арматурою більша на 1,7 \% та 7,3 \% порівняно зі зразками з металевими стержнями.

7. При покритті склокомпозитної арматури матеріалом «СІЛОЛ®» та збільшенні довжини анкерування, збільшується і граничне напруження в стержнях. В усіх зразках руйнівне напруження металевих стержнів дещо більше ніж у зразках з композитною арматурою, але при дворазовому покритті ситуація змінюється на користь склопластику.

\section{References}

1. Chapjuk O., Olekh V., Orjeshkin D. Zcheplennja vazhkogho betonu $\mathrm{z}$ kompozytnoju skloplastykovoju armaturoju, pokrytoju vodovidshtovkhuvaljnoju kompozycijeju SILOL ${ }^{\circledR}$. Suchasni tekhnologhiji ta metody rozrakhunkiv u budivnyctvi. Lucjk: LNTU, 2017. Vyp. 8. S. 253-260.

2. Chapjuk O. Osoblyvosti zcheplennja armatury serpovydnogho profilju z betonom : monoghrafija / O. S. Chapjuk; Lucjkyj nacionaljnyj tekhnichnyj universytet Lucjk: RVV LNTU, 2012. S. 164.

3. Ghryshkova A. Doslidzhennja zcheplennja kompozytnoji skloplastykovoji armatury z vazhkym betonom zalezhno vid klasu betonu. Suchasni tekhnologhiji ta metody rozrakhunkiv u budivnyctvi. Lucjk: 2015. Vyp. 3. S. 53-59.

\section{Список використаних джерел}

1. Чапюк О., Олех В., Орєшкін Д. Зчеплення важкого бетону з композитною склопластиковою арматурою, покритою водовідштовхувальною композицією SILOL®. Сучасні технології та методи розрахунків у будівництві. Луцьк: ЛНТУ, 2017. Вип. 8. С. 253-260.

2. Чапюк О. Особливості зчеплення арматури серповидного профілю 3 бетоном: монографія / О. С. Чапюк; Луцький національний технічний університет - Луцьк: РВВ ЛНТУ, 2012. С. 164.

3. Гришкова А. Дослідження зчеплення композитної склопластикової арматури $з$ важким бетоном залежно від класу бетону. Сучасні технології та методи розрахунків у будівництві. Луцьк: 2015. Вип. 3. С. 53-59. 